\title{
Obituary
}

\section{Mary Bradburn 1918-2000}

Mary Bradburn joined the Mathematical Association in 1940 and was active in it at both national and local levels. She was a pillar of the Thames Valley Branch for many years, right up to her death, serving as both chairman and secretary at various times. At the national level, she was chairman of the old Finance and General Purposes Committee and also served as President of the Association (1994-1995). During the early part of the 1990s, she and I organised jointly the Annual Conference when it was held at Royal Holloway College - a conference which many remember with pleasure, not least for the cello recital in the Picture Gallery. Someone has said 'her life had as many facets and angles as the mathematical models and tessellations that she sometimes used to illustrate her lectures.

Mary was born on 7 March 1918 in the tiny village of Normanby on the edge of the North Yorkshire moors. Her father was a qualified master marine engineer and it is probably no coincidence that, even as a little girl, Mary was attracted by the challenge of mathematics and its applications in the physical world. Her sister tells of their delight on discovering that pails of water could be swung overhead in a complete circle without spilling the contents. At the age of 11, she left the village school to go to Middlesbrough High School where, on reaching entry to the sixth form, she caused a stir by announcing her wish to do 'scholarship maths'. She used to enjoy recalling the Headmistress's reaction 'But girls don't do mathematics'. Nevertheless, arrangements were made and she duly won both the North Riding Senior Scholarship and a State Scholarship at the age of 17. That was too young for admission to either Oxford or Cambridge so, with characteristic intent, she took the entrance examination for Royal Holloway. She was awarded an Exhibition and entered in October 1935.

As a student, Mary was indeed outstanding. She was awarded First Class Honours Special Maths in 1938, Distinction in Special Subjects 1939 and MSc with Distinction in 1940. The remarkable thing is how she found time to study considering the fullness of her cultural, sporting and social life in the college. The Principal at that time wrote in a testimonial 'She was a most valuable member of the community, a notable swimmer, netball player and gymnast, a captain of the cadet company (equivalent to Ranger Guides), president of the Naturalist Club, a skilled practitioner in stage lighting and scene painting.'

Mary was awarded a University of London Scholarship to do postgraduate research and, in 1941, went to Edinburgh to work with Max Born a Nobel Laureate and world leader in quantum mechanics applied to atomic physics. Her PhD thesis was entitled 'The Statistical Thermodynamics of Crystal Lattices'. She then taught for a period at Edinburgh University and at University College, Dundee. In 1945, she was appointed by Professor W. H. McCrea to the Mathematics Department at Royal Holloway where she 
remained until her retirement in 1980. She held visiting appointments at Harvard, Melbourne University, the University of Ghana and York University, Toronto.

Throughout her career Mary was in demand at university level for her expert knowledge and clear vision of academic priorities. She was chairman of numerous boards of examiners and played a leading role in the maintenance of mathematical standards in teacher training colleges at a time in the 1970s when the University of London was responsible for their certification. She had a hand in almost every college development since 1945, including the admission of male students in 1965. This was a move that she welcomed. One student, in that first entry of men wrote 'To a young undergraduate, Mary was the epitome of the establishment figure - it was therefore a considerable surprise to find her serving food in the men's hall of residence on our first day.' As a strong supporter of admitting men, this was a typical example of how she was to do everything in her power to make it a success.

Mary's retirement from Royal Holloway in 1980 provided the opportunity for her devote more time to her other interests including the British Federation of University Women, school governing bodies, the Englefield Green Gardeners Association, Egham and District Music Club and the Soroptomists Club of Greater London. McCrea, by then Sir William, remarked 'Whatever Mary does, she makes herself an expert in the field. When you see her doing any job you will see an expert at work, but you won't know if she's an expert because she was asked to do the job or if she was asked to do the job because she's an expert.'

JOHN HEBBORN 11 Sykes Drive, Staines, Middlesex TW18 ITA 